\title{
Raising the Bar: Increasing Protection for Athletes in the Olympic Movement from Sexual Harassment and Abuse
}

\begin{abstract}
Anne Marie Burke
After the Larry Nassar and USA Gymnastics scandal surfaced in 2016, the United States enacted a federal act titled "Protecting Victims from Sexual Abuse and Safe Sport Authorization Act of 2017." This Act requires immediate mandatory reporting to the U.S. Center for SafeSport for any alleged child abuse of an amateur athlete who is a minor. An increasing amount of legislation is being passed to address sexual harassment and abuse in sports in the United States; however, the International Olympic Committee (IOC), which governs the Olympic Movement, is lacking in its sexual harassment and abuse policies. This article will address how the IOC's sexual harassment and abuse policies are not as robust as they should be. The amount of attention that the Olympics receives worldwide gives the IOC a global platform to be a leader in taking a stance on sexual harassment and abuse policies.
\end{abstract}

Keywords: sexual harassment, abuse, Olympics, International Olympic Committee, SafeSport

\section{Introduction}

The problem of sexual harassment and abuse of Olympic athletes is an ongoing international disgrace. ${ }^{1}$ The fundamental principle of Olympism is that participation in sport is a human right. ${ }^{2}$ The goal of Olympism is to bring the world together and create a more peaceful society through sport. ${ }^{3}$ The Olympic

\footnotetext{
Although victims of sexual harassment and abuse can be of any gender, and any recommendations in this article as to policymaking in this area applies to all genders, this article will focus on arguing for increased protections in the Olympic Movement by focusing on the experience of female athletes.

2 Olympic Charter, InT'L OlYmpIC Comm. 11 (June 19, 2019), https://www.olympic.org/documents/ olympic-charter.

3 Id.

Anne Marie Burke is a third-year law student at the University of Oregon School of Law, with an expected JD in May 2021. She wishes to thank Rachel Booth and Robert Illig for their input on this article. Email: $\underline{\text { aburke8@uoregon.edu }}$
} 
Movement is the collective action of the athletes, coaches, trainers, doctors, and all other individuals and entities that are engaged to further the goal of Olympism. ${ }^{4}$ Olympism is achievable by creating an atmosphere of Olympic spirit, which embraces friendship, solidarity, and fair play. ${ }^{5}$ The notion of fair play includes respect for the rules and equal treatment of all individuals involved. The sexual harassment and abuse of athletes violates the notion of fair play and the equal treatment of athletes inherent in Olympism and the Olympic Movement. The purpose of this article is to highlight the weaknesses in the Olympic Movement's current system of policies related to sexual harassment and abuse, and to make recommendations on how the Olympic Movement can strengthen protections for these athletes.

Olympic athletes have the right to compete in a safe environment free from sexual harassment and abuse. ${ }^{6}$ This article establishes that the Olympic Movement does not currently provide a safe environment for its athletes and needs to improve its global policies and investigative procedures regarding sexual harassment and abuse. To underline the problem and establish the need for reform, this article will do the following: 1) define sexual harassment and abuse; 2) examine select cases of sexual harassment and abuse of Olympic athletes in recent decades; 3) outline the structure of the Olympic Movement and explain how insufficient policies have enabled sexual harassment and abuse; 4) explore the reform efforts that have shown success in delivering more robust protections to athletes from sexual harassment and abuse; and 5) make recommendations on steps for moving forward. Ultimately, this article will argue for the creation of a Global Center for SafeSport to lead worldwide efforts on ending sexual harassment and abuse in the Olympic Movement.

The Olympic Movement is the overarching term that describes the promotion and development of sport throughout the world through the celebration of the Olympic Games. ${ }^{7}$ The International Olympic Committee (IOC), an international non-governmental organization (NGO) headquartered in Lausanne, Switzerland, is the supreme authority of the Olympic Movement. ${ }^{8}$ The IOC has a wide range of responsibilities, including overseeing the activities of all the affiliated athletes,

\footnotetext{
${ }^{4}$ Leading the Olympic Movement, InT'L Olympic Comm., https://www.olympic.org/the-ioc/leading-the-olympic-movement (last visited March 25, 2020).

5 Olympic Charter, supra note 2.

${ }^{6}$ See id.

7 See Who We Are, InT'L Olympic Comm., https://www.olympic.org/about-ioc-olympic-movement (last visited March 26, 2020).

8 IOC formally opens \$145M new headquarters in Switzerland, USA Today (June 23, 2019), https://www.usatoday.com/story/sports/olympics/2019/06/23/ioc-formally-opens-145m-new-headquarters-in-switzerland/39615057/.
} 
organizations, and other individuals involved in the promotion, competition, or administration of the Olympic Games. ${ }^{9}$ The IOC is also responsible for recognizing and overseeing the work of 35 international sports federations (IFs), each of which manages a sport or group of Olympic sports at the global level. ${ }^{10}$ The IOC has governing authority over 206 National Olympic Committees (NOCs), who foster the principles of Olympism in each country or territory that participates in the Olympic Movement. ${ }^{11}$ Each NOC, in turn, recognizes national governing bodies (NGBs) in each country or territory to oversee a particular sport or group of sports in that country or territory. ${ }^{12}$ Local associations, organizations, clubs, and athletes that belong to an NOC or IF are also part of the Olympic Movement. ${ }^{13}$ The scope of the Olympic Movement is wide, and encompasses a large number of vulnerable athletes. For example, the sport of football (soccer) is governed by the International Federation of Association Football (FIFA). FIFA is just one of the 39 Summer and Winter Olympic IFs under the IOC umbrella. ${ }^{14}$ In a FIFA survey conducted in 2014, FIFA reported that 4.8 million female athletes were registered in one of FIFA's member associations around the world, and $54 \%$ of them were below the age of $17 .{ }^{15}$ This FIFA statistic only covers female registered participants and provides data for one sport; if similar data were found for male and female athletes in all 39 IFs, the scope and reach of the IOC would be an enormous number. In sum, the IOC is undoubtedly the most powerful force in sports worldwide and is therefore the appropriate authority to look to for reform in the area of sexual harassment and abuse in the Olympic Movement.

Reaching a world-wide consensus on what constitutes sexual harassment and abuse is crucial to addressing issues of inadequate regulation and protection. Part I of this article will define sexual harassment and abuse, and demonstrate how countries differ in handling offenses of this nature. Part I will also discuss the

\footnotetext{
9 Who We Are, supra note 7.

10 International Sports Federations, InT'L Olympic Comm., https://www.olympic.org/ioc-governance-international-sports-federations (last visited March 26, 2020); Women in the Olympic Movement, Int'1 Olympic Comm. 2 (Feb. 7, 2018), https://stillmed.olympic.org/media/Document\%20Library/OlympicOrg/Factsheets-Reference-Documents/Women-in-the-Olympic-Movement/Factsheet-Women-in-the-Olympic-Movement-February-2018.pdf.

${ }_{11}$ National Olympic Committees, INT'L OLYMPIC Comm., https://www.olympic.org/national-olympic-committees (last visited March 26, 2020).

12 Matthew J. Mitten et al., Sports Law and Regulation: Cases, Materials, and Problems 270 (2016).

13 See Who We Are, supra note 7.

14 Members, The Ass'N of Summer Olympic InT'L Fed'Ns, https://www.asoif.com/members (last visited July 26, 2020); International Sports Federations, InT'L OlympIC Comm., https://www.olympic.org/ioc-governance-international-sports-federations (last visited July 26, 2020).

15 FIFA Women's Football Survey 2014, FIFA 48 (2014), https://resources.fifa.com/image/upload/ fifa-women-s-football-survey-2522649.pdf?cloudid=emtgxvp0ibnebltlvi3b.
} 
human rights protections set forth in several international conventions including the Universal Declaration of Human Rights (UDHR) and the Convention on the Elimination of all Forms of Discrimination Against Women (CEDAW). These conventions, which proclaim that freedom from degrading treatment and discrimination based on sex are basic human rights, acknowledge that protecting people from sexual harassment and abuse is a responsibility of the global community. ${ }^{16}$

Protecting elite athletes from sexual harassment and abuse presents unique challenges that are different from the challenges faced by athletes of lesser accomplishment. Part II will address the particular problems that arise in elite-level sports with regard to sexual harassment and abuse. The failure to protect athletes from sexual harassment and abuse has led to scandals in many sports organizations. Part II will examine three specific sexual abuse scandals in the Olympic Movement. The first case involves Larry Nassar, a former doctor for USA Gymnastics. The second case involves Didier Gailhaguet, the former President of the French Federation of Ice Sports. The third case involves Keramuudin Karim, the former President of the Afghanistan Football Federation.

The IOC is the supreme governing body responsible for carrying out the vision of the Olympic Movement to build a better world through sport. ${ }^{17}$ The IOC also has the difficult task of establishing guidelines for 206 NOCs and 39 IFs, which represent a wide range of cultures and societies in the world. ${ }^{18}$ Part III will outline the structure of the Olympic Movement and provide an overview of the IOC's role and authority. This part will explain why the IOC has historically provided its athletes with inadequate protections against sexual harassment and abuse. Part III also analyzes the IOC's Olympic Charter and Code of Ethics, concluding that these policies have failed to provide robust protections to athletes and lack sufficient sanctions and penalties for perpetrators of sexual harassment and abuse. This part will also explore how the IOC's lack of effective regulations and sanctions against sexual harassment and abuse contrasts with the IOC's comprehensive policies for handling doping violations within the Olympic Movement. The IOC's system for combating doping violations gives hope for the possibility of a more extensive system for processing sexual harassment and abuse violations within the Olympic Movement as well.

Part IV highlights existing legislative and reform efforts in the area of sexual harassment and abuse and the need for increased efforts by the IOC to provide

\footnotetext{
16 See Universal Declaration of Human Rights, G.A. Res. 217 (III) A, pmbl. (Dec. 10, 1948) [hereinafter UDHR]; see also Convention on the Elimination of all Forms of Discrimination Against Women, GA Res. 34/180 (Dec. 18, 1979) [hereinafter CEDAW].

17 See Who We Are, supra note 7.

18 Women in the Olympic Movement, supra note 10; National Olympic Committees, supra note 11.
} 
global protection. This part explores the role of the Court of Arbitration for Sport (CAS), the IOC's current system of adjudicating disputes, and the Safe Sport Act passed by Congress in 2018 .

Part $\mathrm{V}$ offers recommendations to address the issues of sexual harassment and abuse in the Olympic Movement. First, it will argue that the IOC is the organization best positioned to develop new policies to protect athletes against sexual harassment and abuse. Second, it calls on the IOC to clarify what constitutes sexual harassment and abuse by amending the Olympic Charter and Code of Ethics. Third, it calls on the IOC to implement mandatory training and education in the Olympic Movement to work towards creating an environment that is free from sexual harassment and abuse. This recommended IOC system would require all individuals and organizations within the Olympic Movement to promptly report allegations of sexual harassment and abuse against athletes. The system would also maintain a global database of all individuals that have received discipline for a sexual harassment and abuse violations. Fourth, the article calls on the IOC to hold IFs, NOCs, and NGBs vicariously liable if any of these institutions are negligent in failing to prevent sexual harassment and abuse from taking place or failing to investigate or report allegations of sexual harassment and abuse. Fifth, it calls on the IOC to establish a system similar to what the U.S. Olympic Committee (USOC) and U.S. Congress have established in the US through the Safe Sport Act and the U.S. Center for SafeSport.

\section{Sexual Harassment and Abuse Overview and Definitions}

The following definitions of sexual harassment and sexual abuse shall apply throughout this article. The United Nations' Glossary on Sexual Exploitation and Abuse defines sexual harassment as "unwanted verbal, non-verbal or physical conduct of a sexual nature with the purpose or effect of violating the dignity of a person, in particular when creating an intimidating, hostile, degrading, humiliating or offensive environment." ${ }^{\prime 19}$ Whereas, sexual abuse is defined as "actual or threatened physical intrusion of a sexual nature, whether by force or under unequal or coercive conditions." ${ }^{20}$ The key difference between sexual harassment and sexual abuse is that sexual harassment acts can be verbal, non-

\footnotetext{
19 Glossary on Sexual Exploitation and Abuse, U.N. 5 (July 24, 2017), https://hr.un.org/sites/ hr.un.org/files/SEA\%20Glossary\%20\%20\%5BSecond\%20Edition $\% 20-\% 202017 \% 5$ D $\% 20-\% 20$ English 0.pdf.

20 Id.
} 
verbal, or physical conduct, while sexual abuse explicitly involves physical intrusion. ${ }^{21}$

The United Nations (UN) has adopted the aforementioned definitions and, through the UDHR and CEDAW, has inferred freedom from sexual harassment and abuse is a basic human right. ${ }^{22}$ Although the UN's documents have reached a consensus on the protections that should be afforded to each person in regards to sexual harassment and abuse, countries differ on how they handle the issue. Factors such as societal customs, practices, culture, and religion impact how a country shapes its laws on sexual harassment and abuse. Sexual harassment and abuse are global problems, yet each country enacts laws addressing these behaviors differently. As an example, the age of consent ${ }^{23}$ varies widely around the world, from age 12 in the Philippines and Angola up to age 18 in a number of countries as well as many states in the US. ${ }^{24}$ A transnational organization like the IOC must attempt to harmonize the collective response of how all its members handle sexual harassment and abuse.

\section{A. Freedom from Sexual Harassment and Abuse: A Basic Human Right}

Several UN treaties suggest that freedom from sexual harassment and abuse is a basic human right. ${ }^{25}$ Establishing this freedom as a basic human right puts the world on notice that sexual harassment and abuse is a grave violation and also empowers victims to face their perpetrators knowing that the perpetrators' actions are considered an offense to civilization. However, the problem is that many societies do not recognize these basic human rights in their laws or, if they do, lack the legal systems to uphold them.

\section{The Universal Declaration of Human Rights}

Guidance from UN declarations and treaties provide the context for the IOC's policies against sexual harassment and abuse. The United Nations General

\footnotetext{
${ }^{21}$ Sarah L. Cook, Lillia M. Cortina \& Mary P. Koss, What's the difference between sexual abuse, sexual assault, sexual harassment, and rape, The Conversation (Sept. 20, 2018), http:// theconversation.com/whats-the-difference-between-sexual-abuse-sexual-assault-sexual-harassment-and-rape-88218.

22 UDHR, supra note 16.

23 The age of consent is the age at which a person is deemed legally competent to consent to sexual relations.

24 Age Of Consent By Country, World Population Rev., https://worldpopulationreview.com/ country-rankings/age-of-consent-by-country (last visited July 29, 2020).

25 See UDHR, supra note 16; see also CEDAW, supra note 16.
} 
Assembly (UNGA) adopted the Universal Declaration of Human Rights (UDHR) in $1948 .{ }^{26}$ Today, all 192 member states of the UN have ratified the UDHR. ${ }^{27}$ The UDHR provides "a common standard of achievement for all peoples and all nations." 28 The first principle in Article 1 of the UDHR states "all human beings are born free and equal in dignity and rights. They are endowed with reason and conscience and should act towards one another in a spirit of brotherhood." ${ }^{29}$ The failure of sexual harassers and abusers to treat their victims with respect and decency clearly violates this principle. Additionally, since the UDHR reflects a standard that all people, and not just nations, should achieve, the failure of the IOC to adequately protect Olympic athletes from sexual harassment and abuse violates the UDHR.

\section{The Convention on the Elimination of all Forms of Discrimination Against Women}

In 1979, the UNGA adopted the Convention on the Elimination of all Forms of Discrimination Against Women (CEDAW) to serve as a legally binding treaty eliminating gender-based discrimination. ${ }^{30}$ Article 3 of CEDAW states that nations shall take "all appropriate measures, including legislation, to en sure [sic] the full development and advancement of women, for the purpose of guaranteeing them the exercise and enjoyment of human rights and fundamental freedoms on a basis of equality with men." ${ }^{31}$ Therefore, CEDAW should form the international foundation for IOC regulations protecting female athletes from sexual harassment and abuse.

It is noteworthy that seven countries, most notably the United States, have not ratified CEDAW. ${ }^{32}$ The U.S. Senate has held hearings to ratify CEDAW five times since 1988, but each time the hearings have failed to lead to a Senate vote. ${ }^{33}$ Opponents of ratification argue that ratifying CEDAW would violate US sovereignty

\footnotetext{
${ }_{26}$ The Universal Declaration on Human Rights is 70, U.N., https://archives.un.org/content/universal-declaration-human-rights (last visited March 22, 2020).

27 United Nations Universal Declaration of Human Rights, Youth For Hum. Rts., https://www. youthforhumanrights.org/what-are-human-rights/universal-declaration-of-human-rights/introduction.html (last visited March 22, 2020).

28 UDHR, supra note 16.

29 Id. at art. 1.

30 CEDAW, supra note 16.

${ }^{31}$ Id. at art. 3.

32 Lisa Baldez, Why Hasn't the US Ratified the UN Women's Rights Convention? 1 (Paper presented at the Annual Meeting of the American Political Science Association, Seattle, Washington, Sept. 1, 2011).
}

33 Id. 
and would give the treaty committee authority that supersedes US law. ${ }^{34}$ However, this argument fails to acknowledge the fact that the US has ratified four other UN treaties that give the treaty committee superseding authority over US law. ${ }^{35}$ The fact that the US has only signed and not ratified CEDAW means that CEDAW is not legally binding in the US. ${ }^{36}$ Instead, the US only has the good faith obligation to act in accordance with the stipulations in the treaty. ${ }^{37}$ The failure of ratification in the US makes it more likely that other countries will also place a lower importance on women's rights. Moreover, without strong US support, it is unrealistic to expect that trans-national non-governmental organizations, such as the IOC, will feel impelled to enact policies that reflect these values.

\section{B. Sexual Harassment and Abuse: A Global Problem}

Sexual harassment and abuse of women is a global problem: there is no society where sexual harassment and abuse does not exist. ${ }^{38}$ The persistent idea of male sexual entitlement, the notion that men are accorded the dominant role in society and therefore cannot be held accountable when they sexually harass and abuse women, is the source of much of the problem. ${ }^{39}$ This notion exists in the US, where sexual harassment and abuse scandals have emerged in Hollywood, the restaurant industry, the Catholic Church, and even the armed forces. ${ }^{40}$

In Asian countries, gender inequality and male sexual entitlement have resulted in high levels of sexual harassment and abuse. ${ }^{41}$ Male sexual entitlement

\footnotetext{
34 Id. at 20, 23.

35 Where the United States Stands on 10 International Human Rights Treaties, THE LEADERSHIP Conf. Educ. Fund (Dec. 10, 2013), https://civilrights.org/edfund/resource/where-the-united-statesstands-on-10-international-human-rights-treaties/.

36 Glossary, U.N. Treaty Collection, https://treaties.un.org/Pages/Overview.aspx?path=overview/glossary/pagel_en.xml\#signaturead (last visited Jan. 20, 2020).

${ }^{37} I d$.

38 Meera Senthilingam, Sexual Harassment: How it stands around the globe, CNN (Nov. 29, 2017), https://www.cnn.com/2017/11/25/health/sexual-harassment-violence-abuse-global-levels/ index.html.

39 See id.

40 See Sarah Almukhtar, Michael Gold \& Larry Buchanan, After Weinstein: 71 Men Accused of Sexual Misconduct and Their Fall From Power, N.Y. Times (Feb. 8, 2018), https://www.nytimes. com/interactive/2017/11/10/us/men-accused-sexual-misconduct-weinstein.html; Wendy Ruderman, 'Absolutely disgusting': Catholics in Philadelphia react to the latest child sex-abuse scandal, The Phila. InquiRer (Dec. 29, 2019), https://www.inquirer.com/news/catholic-church-priests-sexual-child-abuse-philadelphia-20191229.html; Paula Coughlin, Marine nude photos a leadership disaster: Tailhook whistle-blower, USA ToDAY (March 9, 2017), https://www.usatoday.com/story/ opinion/2017/03/09/military-failing-women-decades-paula-coughlin-column/98909892/.

${ }^{41}$ Senthilingam, supra note 38.
} 
is the expectation that women exist to sexually pleasure men based on their objectification of women and girls. ${ }^{42}$ The fact that public spaces in Asian countries are mostly controlled by men creates a social norm wherein men perceive they have ownership over women, and this ownership gives them the right to sexually harass and abuse women in public. ${ }^{43}$ In 2015 and 2016, ActionAid, an international non-profit charity, conducted two studies that found the percentage of women who have experienced sexual harassment was $57 \%$ in Bangladesh, $77 \%$ in Cambodia, $79 \%$ in India, and $86 \%$ in Thailand. ${ }^{44}$ These statistics still show very high levels of prevalence of sexual harassment and abuse even though incidents of sexual harassment and abuse are usually under-reported. ${ }^{45}$

Sexual harassment and abuse tied to male entitlement is prevalent in Latin America as well. ${ }^{46}$ In a study conducted by the National Institute of Statistics and Geography, $96 \%$ of the women surveyed in Mexico City experienced sexual violence in public. ${ }^{47}$ Additionally, in Brazil, $84 \%$ of women reported having been sexually harassed by the police. ${ }^{48}$ Other issues that contribute to high incidences of sexual harassment and abuse include poor infrastructure, overcrowded transportation, and women needing to work late or unusual hours. ${ }^{49}$

Countries in the Middle East and North Africa heavily stigmatize sexual harassment and abuse of women. ${ }^{50}$ Some forms of sexual harassment and abuse in these countries are even legal..$^{51}$ For example, a number of Arab countries in this region permit female genital mutilation and child marriage. ${ }^{52}$ Additionally, laws in eight Middle Eastern and North African countries permit rapists to escape punishment if they marry their victims..$^{53}$ The varying social and cultural norms in each country impacts how the legal system prosecutes or fails to prosecute sexual harassment and abuse crimes.

\footnotetext{
42 See id.; Forum: Recent cases show a culture of male sexual entitlement, THE STRAITS Times (Jan. 17, 2020), https://www.straitstimes.com/forum/forum-recent-cases-show-a-culture-of-male-sexual-entitlement.

43 Senthilingam, supra note 38.

44 Women's rights organizations key to ending violence against women and girls in our rapidly urbanizing world, AстIONAID (May 2016), https://www.actionaid.org.uk/sites/default/files/publications/safe cities for women may 2016.pdf; Women and the City III, ActionAid (Feb. 2015), https://actionaid.org/sites/default/files/women_and the city_iii.pdf.

${ }^{45} I d$.

46 Senthilingam, supra note 38.

47 Id.

48 Id.

49 Id.

$50 \quad I d$.

${ }_{51}$ See id.

52 Id.

${ }_{53} I d$.
} 


\section{The Handling of Sexual Harassment and Abuse Cases Around the World}

Contrasting how different countries handle sexual harassment and abuse crimes is key to understanding why a more uniform system is beneficial to protect victims. In the US, the criminal justice system is available to victims of sexual harassment and abuse to pursue redress. ${ }^{54}$ The prosecution of guilty perpetrators and the possibility of punishment, including imprisonment, should be the strongest deterrent against this behavior. However, it is unfortunate that sexual harassment and abuse claims are notoriously difficult to prosecute. The standard of proof in a criminal case in US courts is proof beyond a reasonable doubt. ${ }^{55}$ This is a high burden to meet in a case of sexual harassment and abuse since the offense is often committed in private, leading to a lack of direct evidence and a need to rely heavily on the victim's testimony. ${ }^{56}$ Women generally are reluctant to endure the harsh process of testifying during cross-examination. ${ }^{57}$ This process causes additional challenges in child sexual harassment and abuse cases, because the court process involves many stages of questioning, providing ample opportunity to instill fear and guilt in the child, making it more likely for the child to recant or testify inconsistently with prior statements. ${ }^{58}$ Therefore, without the victim's willingness or ability to testify consistently, it is difficult for the government to prosecute sexual harassment and abuse crimes. ${ }^{59}$

Women in other countries also must rely on their country's criminal law systems that often do not provide them adequate protection. For example, even though the Democratic Republic of the Congo, Burundi, Namibia, Lesotho, and South Africa updated their criminal laws in 2011 to include additional forms of sexual violence and sex-related offenses, this does not ensure that these crimes

\footnotetext{
54 The Difference Between Civil Sexual Assault and Criminal Sexual Assault, Berry L., https:// victimsofcrime.org/media/reporting-on-child-sexual-abuse/criminal-and-civil-justice (last visited March 23, 2020).

55 Benjamin Rachlin, Who to Believe, The New Republic (Dec. 3, 2018), https://newrepublic.com/ article/152305/who-to-believe-sexual-assault.

56 John E.B. Myers, The Child Witness: Techniques for Direct Examination, Cross-Examination, and Impeachment, 18 PAC. L.J. 801, 828 (1987), https://scholarlycommons.pacific.edu/cgi/viewcontent.cgi?article $=1071 \&$ context $=$ facultyarticles.

57 See Carolyn Copps Hartley \& Roxann Ryan, Prosecution Strategies in Domestic Violence Felonies: Anticipating and Meeting Defense Claims 9 (2002), https://www.ncjrs.gov/pdffiles1/nij/ grants/194075.pdf.

58 Hartley, supra note 57 at 834.

59 Rachlin, supra note 55.
} 
will be prosecuted effectively in these jurisdictions. ${ }^{60}$ In Bangladesh, access to the legal system is onerous. ${ }^{61}$ Even though Bangladesh has laws that criminalize sexual harassment, victims of sexual harassment in Bangladesh, especially women, do not have access to the criminal justice system to get redress. ${ }^{62}$

Processing a case through the civil court system in the US provides another avenue for holding perpetrators accountable and has some advantages over the criminal justice system. One advantage is that the standard of proof in a civil case is by a preponderance of evidence, which is a lower standard of proof than the criminal justice system. ${ }^{63}$ There are also more options for providing reparations to victims, including monetary compensation for the victim's pain and suffering ${ }^{64}$ However, there are also some disadvantages to the civil system. Perpetrators can require victims to sign non-disclosure agreements in exchange for agreement to a monetary settlement. ${ }^{65}$ Although California and New York have had laws in effect since 2019 that restrict non-disclosure agreements in sexual harassment and abuse cases, most states do not have this type of law, making it easier for perpetrators to keep their predatory sexual behavior secret and escape public backlash. ${ }^{66}$

The civil system also offers a way to hold organizations and institutions vicariously liable. In the US, Title VII of the Civil Rights Act of 1964 began holding employers accountable for individual employees' behavior. ${ }^{67}$ The concept of vicarious liability emerged in cases in which employers that were negligent in failing to address a hostile and toxic environment in which sexual harassment and abuse more easily occurred bore some responsibility to compensate the

\footnotetext{
${ }_{60}$ See Kim Sellinger, Helene Silverberg \& Robin Mejia, The Investigation and Prosecution of Sexual Violence 4 (Hum. Rts. Ctr. U.C. Berkeley, Working Paper May 2011), https://www.law. berkeley.edu/wp-content/uploads/2015/04/The-Investigation-and-Prosecution-of-Sexual-Violence-SV-Working-Paper.pdf.

${ }_{61}$ Shahnaz Huda, Sexual Harassment and Professional Women in Bangladesh, 4 Asia-PAC. J. ON Hum. RTs. \& L. 52, 65 (2003).

${ }^{62} I d$.

${ }^{63} I d$.

${ }^{64}$ Sexual Harassment - Legal Standards, wORKPLACE FAIRNESS, https://www.workplacefairness. org/sexual-harassment-legal-rights (last visited July 31, 2020).

${ }_{65}$ Stacy Perman, \#MeToo law restricts use of nondisclosure agreements in sexual misconduct cases, L.A. Times (Dec. 31, 2018) https://www.latimes.com/business/hollywood/la-fi-ct-nda-hollywood-20181231-story.html.

${ }^{66} I d$.

${ }^{67}$ Anita Moorman \& Lisa P. Masteralexis, An Examination of the Legal Framework between Title VII and Title IX Sexual Harassment Claims in Athletics and Sports Settings: Emerging Challenges for Athletics Personnel and Sport Managers, J. of Legal Aspects of Sports 101, 102 (Dec. 1, 2007).
} 
victim. ${ }^{68}$ Vicarious liability means that employers can no longer argue they have no duty to protect employees from incidents of sexual harassment and abuse in their workplace. ${ }^{69}$ This concept forces institutions to address the problem and helps counter the bystander effect.

Although the UDHR and CEDAW outline rights women around the world are entitled to, it is still up to each country and its court system to implement and enforce these protections. Due to societal and cultural norms, countries vary in the amount of protections their legal systems provide victims of sexual harassment and abuse. The IOC cannot expect that protection from sexual harassment and abuse in the Olympic Movement can be left to the laws of individual countries. Introducing vicarious liability into the organizations comprising the Olympic Movement would be a beneficial strategy for the IOC to implement, since the IOC, as an NGO, cannot bring criminal charges. Using the theory of vicarious liability, the IOC could bring pressure on the IFs, NOCs, and NGBs to create a safe environment for athletes that is free from sexual harassment and abuse. It is paramount to develop a system that provides supreme authority for processing sexual harassment and abuse violations in the Olympic Movement and one that will force accountability on organizations and not simply on individuals within organizations.

\section{Sexual Harassment and Abuse in Sports and the Olympic Movement}

Sexual harassment and abuse in sports is widespread..$^{70}$ Understanding some of the risk factors inherent in sport will shed light on why female athletes in the Olympic Movement are more vulnerable to sexual harassment than female athletes performing at lower levels in sport. Among the increased risk factors, four are highlighted: 1) the athletes are young; 2) elite athletes have more at stake than recreational athletes; 3 ) elite athletes spend large amounts of time with their coaches, trainers, and physicians, among other staff; and 4) the Olympic Movement has a gender imbalance creating a male-dominated environment. This section discusses three examples that illustrate how these risk factors contribute to the persistence of sexual harassment and abuse in the Olympic Movement regardless of the athlete's citizenship or the sport in which the athlete participates.

\footnotetext{
68 Amy Mathews, The Sexual Harassment Revolution: Employer Liability for Third Party Sexual Harassment, 65 U. Mo. Kansas City L. Rev. 977 (1997).

69 Id. at 990.

70 Margo Mountjoy et al., The IOC Consensus Statement: Harassment and Abuse (non-accidental violence) in Sport, British J. of Sports Med. 1019, 1024 (Apr. 26, 2016), https://bjsm.bmj.com/ content/bjsports/50/17/1019.full.pdf.
} 


\section{A. Olympic Movement's Unique Environment}

The Olympic Movement is an environment in which elite female athletes are particularly vulnerable to sexual harassment and abuse. From 1982-2017, nearly 300 coaches and officials spanning 15 different US Olympic sports organizations were publicly accused of sexual misconduct. ${ }^{71}$ And, from 2017-2019 more than 600 individuals associated with US Olympic sports organizations have been permanently sanctioned from participating in sport due to egregious physical, emotional, or sexual misconduct. ${ }^{72}$ These statistics are unsurprising because sexual perpetrators see aspiring Olympic athletes as prime targets of sexual harassment and abuse. ${ }^{73}$ There are several reasons for why elite female athletes are targets, and this section will discuss four.

First, aspiring Olympians typically begin their careers as young children. For example, four-time Olympic gold medalist Simone Biles began training in gymnastics when she was 6 years old. ${ }^{74}$ Remarkably, when it comes to competing in gymnastics for the U.S. National Olympic Team, Biles actually was above the average age that most future gymnasts start training, which is between 2 and 5 years old..$^{75}$ Because of their developmental needs, young athletes are more vulnerable to abuses of the power imbalance inherent in the coach-athlete relationship. ${ }^{76}$ A study conducted in the UK in 2011 reported $24 \%$ of athletes under the age of 16 experienced physical abuse. ${ }^{77}$ A separate study in 2008 in the Netherlands showed that 1 in 5 participants in sport aged 12 or over reported being a victim or witness to verbal aggression, physical aggression, or sexual harassment. ${ }^{78}$ Children and young athletes are also usually unaware of their personal rights and too intimidated to object to sexual conduct initiated by an adult. ${ }^{79}$

\footnotetext{
71 Will Hobson \& Steven Rich, Every six weeks for more than 36 Years: When will sex abuse in Olympic sports end?, THE WAsH. Post (Nov. 17, 2017), https://www.washingtonpost.com/ sports/every-six-weeks-for-more-than-36-years-when-will-sex-abuse-in-olympic-sportsend/2017/11/17/286ae804-c88d-11e7-8321-481fd63f174d story.html.

72 U.S. Center for SafeSport 2019 Annual Report, U.S. Ctr. For SAFESPORT 9 (Dec. 2019), https:// www.flipsnack.com/safesport/u-s-center-for-safesport-2019-annual-report.html.

73 Steve Cornelius \& Paul Singh, Protection of Young Athletes, in HandBook of InT'L Sports L. 294 (James A.R. Nafziger \& Stephen F. Ross eds., 2011).

74 Sarah Fielding, What Age Do Most Olympians Start Training?, Bustle (Feb. 15, 2018), https:// www.bustle.com/p/what-age-do-most-olympians-start-training-many-are-children-when-they-begin-learning-their-sport-7935404.

75 Id.

76 Mountjoy, supra note 70 , at 1023.

77 Tine Vertommen et al., Interpersonal Violence Against Children in Sport in the Netherlands and Belgium, 51 Child Abuse \& Neglect 223, 224 (2016).

78 Id.

79 Mountjoy, supra note 70 , at 1023.
} 
Therefore, young athletes are particularly vulnerable to sexual harassment and abuse and, as a result, need more protection against this behavior.

The second risk factor is that aspiring Olympians are elite athletes and must make many more sacrifices than the average recreational athlete to achieve their dreams of competing in the Olympic Games. The demands of competing at a high level creates pressure from many difference sources that have invested in the athlete's success: coaches, parents, teams, IFs, NOCs, NGBs, and the athlete herself. ${ }^{80}$ Whereas the average recreational athlete has relatively less to lose by quitting a sport, an elite athlete has the pressures of many stakeholders to consider before quitting a sport entirely. A 2010 study of female athletes in the Czech Republic found that the percentage of athletes harassed by authority figures within their sport increased with performance level, from $29.7 \%$ among non-elite level athletes to $55.2 \%$ among elite-level athletes. ${ }^{81}$ The fact that elite athletes are less likely to quit a sport puts the elite athlete at risk of mistreatment from predatory coaches, doctors, and officials who would take advantage of these pressures by threatening the athletes' careers if the victims report the sexual harassment and abuse.

A third risk factor is that athletes spend many hours training for the Olympic Games. ${ }^{82}$ For example, the five women on the USA Gymnastics' all-around competition on average trained 32-36 hours a week in the leadup to the 2016 Summer Olympic Games. ${ }^{83}$ Athletes spend a significant amount of training time with their coaches and entourage. Much of this time is spent unsupervised in locker rooms, offices, medical examination rooms, and hotel rooms when traveling for competitions. ${ }^{84}$ Consequently, sexual predators have many opportunities to sexually harass and abuse elite athletes. ${ }^{85}$

\footnotetext{
80 Mountjoy, supra note 70, at 1023.

81 Kari Fasting, Celia Brackenridge and Nada Knorre, Performance Level and Sexual Harassment Prevalence Among Female Athletes in the Czech Republic, 19 Women In SPORT AND PhysicAL Activity J. 29, 30 (April 2010), https://www.researchgate.net/publication/49401866_Performance Level and Sexual Harassment_Prevalence among_Female Athletes in the Czech Republic. For purposes of this study, elite-level athlete was defined as an athlete that trained at least four times a week and had participated in an Olympic Games, a European Championship, a World Championship, or had competed at the international level within the previous 1-2 years. Non-elite level athletes were those competing in a sport but did not qualify as the elite level.

82 See Andrea Frazier, How Many Days a Week Does Simone Biles Train? She Puts In The Time, RoMPer (Aug. 11, 2016), https://www.romper.com/p/how-many-days-a-week-does-simone-bilestrain-she-puts-in-the-time-16236.

83 Id.

${ }^{84}$ Mountjoy, supra note 70 , at 1021.

85 Id.
} 
A fourth risk factor is that the Olympic Movement is a male-dominated environment with an enormous gender imbalance. ${ }^{86}$ In the four Olympic Games spanning 2010-2016 (Vancouver, London, Sochi, and Rio) on average only $10 \%$ of accredited coaches at the Olympic Games were women and only $29 \%$ of accredited officials were women. ${ }^{87}$ Additionally, out of 204 NOCs surveyed in $2008,{ }^{88}$ only 17 had female presidents, a lowly $8 \% .{ }^{89}$ Similarly, of the 35 IFs, only two had female presidents. ${ }^{90}$ Yet, $42.5 \%$ of athletes participating in the four Olympic Games from 2010-2016 were female. ${ }^{91}$ Having a grossly disproportionate number of men in power positions within the Olympic Movement creates a two-fold problem for female athletes. First, a female athlete is at risk from predatory males in positions of authority over them. Second, an athlete's allegation against a male perpetrator is likely to be heard by a male official, who is often unsympathetic to a sexual harassment and abuse claim from a female. As a result, sport becomes a risky environment, one more prone to sexual harassment and abuse than many other situations in life.

\section{B. USA Gymnastics and the Case of Larry Nassar}

The Larry Nassar scandal highlights how several of the risk factors discussed lead to the difficulty of protecting against sexual harassment and abuse in the Olympic Movement. Nassar was a physician who worked for USA Gymnastics, which is the NGB of gymnastics in the US. ${ }^{22}$ Nassar also worked in the athletics department at Michigan State University, and in these roles Nassar sexually abused female athletes for more than three decades. ${ }^{93}$ Since 2016, more than

\footnotetext{
86 See IOC Gender Equality Review Project, InT’L Olympic Comm. (March 2018), https://stillmed. olympic.org/media/Document\%20Library/OlympicOrg/News/2018/03/IOC-Gender-Equality-Report-March-2018.pdf.

87 Id. at $12-13$.

88 There were two National Olympic Committees that did not participate in the survey.

89 Women in the Olympic Movement, supra note 10.

90 Id.

91 Factsheet Women in the Olympic Movement, InT'L Olympic Comm. 4-5 (Feb. 2018), https:// stillmed.olympic.org/media/Document\%20Library/OlympicOrg/Factsheets-Reference-Documents/Women-in-the-Olympic-Movement/Factsheet-Women-in-the-Olympic-Movement-February-2018.pdf.

92 About USA Gymnastics, USA GymnASTICs, https://usagym.org/pages/aboutus/pages/about usag.html (last visited March 23, 2020).

93 Emma Winowiecki, Kay Lafond, Mark Brush \& Kate Wells, Timeline: A Long History of Abuse by Dr. Larry Nassar, Mich. Radio (Jan. 24, 2018), https://www.michiganradio.org/post/ timeline-long-history-abuse-dr-larry-nassar.
} 
350 victims have accused Nassar of sexual abuse. ${ }^{94}$ Nassar used his authority as a doctor to disguise his sexual abuse as necessary medical treatment. ${ }^{95}$ From 1997-2004 there were several instances of athletes ranging in age from 12 to 17 years old who told their coaches, parents, and trainers about Nassar's sexual abuse. ${ }^{96}$ However, their complaints were often disbelieved or minimized. ${ }^{97}$ One female coach told the athletes they misunderstood what Nassar had done, and several other coaches told the athletes that they should trust Nassar since he was a well-respected doctor. ${ }^{98}$ The first time police investigated a report of sexual abuse involving Nassar was in October 2004, when the Michigan police received a victim's 88-page complaint alleging abuse by Nassar. ${ }^{99}$ During the police interview, Nassar claimed he was performing a legitimate medical procedure to treat the victim's scoliosis and handed police a PowerPoint presentation he created documenting this technique. ${ }^{100}$ The police believed Nassar over the victim, and since the police did not think that Nassar committed a crime the police never sent the case to the local prosecutors. ${ }^{101}$

In Nassar's case, results in the civil justice system were mixed. Among the reasons Nassar was able to sexually abuse victims for decades without being caught was the use of nondisclosure agreements, the skepticism adults had of many of the young victims' allegations, and the bystander effect. In 2016, American gymnast McKayla Maroney settled a civil lawsuit with USA Gymnastics and received $\$ 1.25$ million in exchange for her silence relating to claims that Nassar sexually abused her. ${ }^{102}$ The nondisclosure agreement did not allow Maroney to

\footnotetext{
94 Sarah Fitzpatrick, Tom Costello \& Adiel Kaplan, Congress: U.S. Olympic Committee, FBI Failed to Protect Athletes from Larry Nassar's Abuse, NBC News (July 30, 2019), https://www. nbcnews.com/politics/congress/congress-u-s-olympic-committee-fbi-failed-protect-athletes-larry-n1035751.

95 How Larry Nassar Abused Hundreds of Gymnasts and Eluded Justice for Decades, InDYSTAR (March 8, 2018), https://www.indystar.com/story/news/2018/03/08/larry-nassar-sexually-abused-gymnasts-michigan-state-university-usa-gymnastics/339051002/.

96 Tracy Connor \& Sarah Fitzpatrick, Gymnastics scandal: 8 times Larry Nassar could have been stopped, NBC News (Jan. 25, 2018), https://www.nbcnews.com/news/us-news/gymnastics-scandal-8-times-larry-nassar-could-have-been-stopped-n841091.

97 Id.

98 Id.

99 Richard Gonzales, Michigan Officer Says He Botched Investigation, Believed Larry Nassar's 'Lies', NPR (March 26, 2019), https://www.npr.org/2019/03/26/707048511/michigan-officer-says-he-botched-investigation-believed-larry-nassars-lies.

100 Id.

101 Id.

102 Kenzie Bryant, USA Gymnastics Paid McKayla Maroney for Silence in Sex Abuse Case, Lawsuit Says, VANity FaIR (Dec. 21, 2017), https:/www.vanityfair.com/style/2017/12/mckayla-maroney-settlement-lawsuit-us-olympics.
} 
publicly share that Nassar sexually abused her and said she could not disparage Nassar or USA Gymnastics. ${ }^{103}$ USA Gymnastics also failed to report Nassar's sexual abuse to law enforcement. ${ }^{104}$ With nondisclosure agreements arising out of civil lawsuits, incidents of sexual harassment and abuse can occur without detection by law enforcement.

Non-intervention by people in authority positions or people with the ability to report a violation creates a bystander effect. ${ }^{105}$ With the bystander effect, an individual aware of abuse sees that other bystanders are not reacting to or placing importance on certain behavior, and therefore also refrains from reacting to a situation, rationalizing that the behavior must be permissible. ${ }^{106}$ In the case of Nassar, from 1997-2015 there were at least eight times in which doctors and coaches received complaints from athletes about Nassar's conduct. ${ }^{107}$ However, none of these complaints led to any substantial investigation into Nassar. ${ }^{108}$ Since those in authority positions failed to take allegations against Nassar seriously, Nassar's abuse continued for years. ${ }^{109}$

It was not until 2017, when the \#MeToo social media campaign went viral that the public finally paid more attention to victims' reports about Nassar. ${ }^{110}$ The \#MeToo movement helped prompt a full investigation into Nassar. ${ }^{11}$ By June 2017, there were 119 women and girls who had filed lawsuits naming Michigan State University, USA Gymnastics, or Nassar as the defendant. ${ }^{112}$ In July 2017, Nassar pleaded guilty to possessing child pornography and received a 60 -year prison sentence. ${ }^{113}$ Then in November 2017, Nassar pleaded guilty to seven counts

\footnotetext{
103 Id.

104 A Blind Eye to Sex Abuse: How USA Gymnastics Fails to Report Cases, IndyStar (Aug. 4, 2016), https:/www.indystar.com/story/news/investigations/2016/08/04/usa-gymnastics-sex-abuse-protected-coaches/85829732/.

105 Mountjoy, supra note 70 at 1024.

106 See Zachary Kaufman, Turning Bystanders into Upstanders Amid Sexual Crimes, Stan. U. (Aug. 10, 2018), https://law.stanford.edu/2018/08/10/turning-bystanders-into-upstanders-amid-sexual-crimes/.

107 Connor, supra note 96.

108 See id.

109 Anna North, Young Women Reported Larry Nassar for Decades. No One Took Them Seriously - Until Now, Vox (Jan. 25, 2018), https://www.vox.com/identities/2018/1/25/16928994/larry-nassar-mckayla-maroney-gymnastics-me-too.

110 Id.

111 Id.

112 Matt Mencarini, 23 more women, girls file lawsuit against MSU, Nassar, Lansing St. J. (June 30, 2017), https://www.lansingstatejournal.com/story/news/local/2017/06/30/23-more-womengirls-file-lawsuit-against-msu-nassar/443945001/.

113 Alanna Vagianos, Larry Nassar Sentenced to 40 to 175 Years in Prison for Child Sexual Abuse, HuffPost (Jan. 24, 2018), https://www.huffpost.com/entry/larry-nassar-sentenced_n_5a$\underline{612 \mathrm{ca} 2 \mathrm{e} 4 \mathrm{~b} 01 \mathrm{~d} 91 \mathrm{~b} 2543 \mathrm{~b} 12 .}$.
} 
of first-degree criminal sexual conduct and received an additional sentence of 40-175 years in prison for his sex crimes. ${ }^{114}$ The \#MeToo movement brought more public attention to victims' accounts of sexual harassment and abuse by Nassar, finally overcoming the bystander effect.

Other American gymnasts besides Maroney also tried to hold USA Gymnastics liable for Nassar's sexual abuse acts. ${ }^{115}$ However, USA Gymnastics stated that the athletes' claims were barred by the statute of limitations. ${ }^{116}$ USA Gymnastics also argued that Nassar's actions were outside of USA Gymnastics' control, because Nassar abused many of the victims while at his home or other locations. ${ }^{117}$ Additionally, USA Gymnastics estimated it would cost the organization between \$75 million and \$100 million to settle the lawsuits, an amount that USA Gymnastics did not have. ${ }^{118}$ USA Gymnastics filed for bankruptcy in December 2018 and framed the filing as a move that would actually help the gymnasts because the bankruptcy filing would expedite payment to the victims. ${ }^{119}$ In January 2020 , USA Gymnastics offered to pay \$215 million from its insurance policies to settle the lawsuit of more than 500 accusers of Nassar. ${ }^{120}$ The lawyer representing the athletes in the lawsuit against USA Gymnastics called the offer unconscionable and further evidence that USA Gymnastics and the USOC do not take sexual abuse seriously. ${ }^{121}$ The victims failed to approve the settlement by May 2020, so USA Gymnastics will not have to resolve the lawsuit until after USA Gymnastics completes its bankruptcy process. ${ }^{122}$ In further repercussions for USA Gymnastics, the USOC has threatened to revoke USA Gymnastics' status as an NGB for its failure to protect athletes from sexual harassment and abuse. ${ }^{123}$ Holding USA

\footnotetext{
114 Id.

115 Nancy Armour, Rachel Axon \& Tim Evans, USA Gymnastics files for bankruptcy, a move related to Larry Nassar's sexual abuse lawsuits, USA TODAY (Dec. 5, 2018), https://www. usatoday.com/story/sports/olympics/2018/12/05/usa-gymnastics-files-bankruptcy-nassar-lawsuits/2218546002/.

116 Jessica Schladebeck, USA Gymnastics argues it's not 'liable' to victims of Larry Nassar's sexual abuse, DAILY News (Dec. 12, 2017), https://www.nydailynews.com/news/national/usa-gymnastics-not-liable-victims-larry-nassar-article-1.3694063.

117 Id.

118 Armour, supra note 115.

119 Id.

120 Michael Levenson, USA Gymnastics Offers \$215 Million to Larry Nassar Victims, N.Y. TimES (Jan 30, 2020), https:/www.nytimes.com/2020/01/30/sports/USA-gymnastics-nassar.html.

121 Id.

122 USA Gymnastics' proprosal to sexual assault survivors rangers from $\$ 83 \mathrm{~K}$ to $\$ 1.25 M$, ESPN, (Feb. 22, 2020), https://www.espn.com/olympics/story/_id/28757570/usa-gymnastics-proposal-sexual-assault-survivors-ranges-83k-125m.

123 Alice Park, U.S. Olympic and Paralympic Committee 'Failed to Protect Its Athletes From Sexual Abuse,' Senate Investigation Determines, Time (July 30, 2019), https://time.com/5638354/ us-olympic-paralympic-committee-congressional-investigation/.
} 
Gymnastics vicariously liable for Nassar's actions is an example the IOC can learn from and implement at a world-wide level for other IFs, NOCs, and NGBs that repeatedly fail to investigate and protect athletes from sexual harassment and abuse claims.

\section{French Federation for Ice Sports and the Case of Didier Gailhaguet}

The French Federation of Ice Sports, ${ }^{124}$ the NGB for figure skating in France, ${ }^{125}$ had issues similar to the Nassar case in its failure to hold a perpetrator accountable for sexual harassment and abuse. ${ }^{126}$ This case also exhibited evidence of gender imbalance in the NGB and the bystander effect contributing to the mishandling of the sexual harassment and abuse allegations. Didier Gailhaguet was the President of the French Federation of Ice Sports from 1998-2004 and from 2007 until his resignation in February 2020. ${ }^{127}$ Sarah Abitbol was a former figure skater who competed in the 1998 Winter Olympic Games. ${ }^{128}$ Abitbol released a book in 2020 that accused her former skating coach, Gilles Beyer, of raping her as a teenager from 1990-1992. ${ }^{129}$ Two other former skaters accused Beyer of sexual harassment and abuse and alleged a lack of support from the French Federation of Ice Sports. ${ }^{130}$ Although the French Sports Ministry conducted an investigation into Beyer in 2000 and reported Beyer had inappropriate behavior with at least one young skater, Gailhaguet still appointed Beyer as France's team leader at the 2001 Junior World Championships. ${ }^{131}$ Gailhaguet said that it was probably through his own naivety or trust that he gave Beyer that role. ${ }^{132}$ In Gailhaguet's resignation speech, he admitted to making mistakes but did not admit he was

\footnotetext{
${ }_{124}$ The French Federation of Ice Sports is translated from Fédération française des sports de glace.

125 Atlas National Des Federations Sportives 2012, Republic of Fr. Ministry of Sports 10 http:// www.sports.gouv.fr/IMG/pdf/atlas.pdf.

126 See Jingnan Huo, French Skating Chief Resigns Amid Sexual Abuse Scandal, NPR (Feb. 8, 2020), https://www.npr.org/2020/02/08/804132625/french-skating-chief-resigns-amid-sexualabuse-scandal.

${ }_{127} I d$.

128 Sarah Abitbol, InT'L Olympic Comm., https://www.olympic.org/sarah-abitbol (last visited April 1, 2020).

129 French ice skating president resigns over sexual abuse scandal, THe GUARdian (Feb. 8, 2020), https://www.theguardian.com/world/2020/feb/08/french-ice-skating-president-resigns-over-sexual-abuse-scandal.

130 Id.

131 France's ice-sports chief resigns amid sexual abuse scandal in figure skating, FR. 24 (Feb. 8, 2020), https://www.france24.com/en/20200208-france-s-ice-sports-chief-resigns-amid-sexualabuse-scandal-in-figure-skating.

${ }^{132}$ French ice skating president resigns over sexual abuse scandal, supra note 129.
} 
ever at fault. ${ }^{133}$ Gailhaguet's words echo those of a bystander who cannot admit he has any duty to intervene into a situation where he is an observer. Gailhaguet's appointment of Beyer as team leader for the French junior team even after documented findings that Beyer repeatedly committed sexually abusive acts on minors shows Gailhaguet failed to place any worth on the victims' experiences.

\section{Afghanistan Football Federation and the Case of Keramuudin Karim}

The case of Keramuudin Karim is an example in which an IF was able to extend protection against sexual harassment and abuse even into a country with no effective criminal laws governing sex crimes. In 2018, reports surfaced that while serving as the President of the Afghanistan Football Federation, the NGB of soccer in Afghanistan, Karim sexually abused at least five women on the female national team. ${ }^{134}$ Karim did not face criminal prosecution for his acts of sex abuse because Afghanistan does not have laws that address this type of behavior. ${ }^{135}$ However, FIFA, as the IF of soccer, banned Karim for life and fined him approximately \$1 million USD. ${ }^{136}$ FIFA ruled that Karim breached Article 23 of the FIFA Code of Ethics, which prohibits all forms of sexual harassment and abuse. ${ }^{137}$ Since the criminal code in Afghanistan did not consider Karim's behavior illegal, the only redress was to hold Karim liable under FIFA's own Code of Ethics. ${ }^{138}$ Karim's case shows the importance of having a governing organization with authority to mandate sanctions and fines for breaches in ethical codes, especially when criminal avenues are not available.

Although the key figures in each of the aforementioned cases faced some form of accountability, the range of outcomes from prison time to a monetary fine is evidence that the safety net for elite female athletes is generally weak and uneven worldwide. The US legal system helped Nassar's victims seek justice

\footnotetext{
133 France's ice-sports chief resigns amid sexual abuse scandal in figure skating, supra note 131.

134 Suzanne Wrack, 'There was Blood Everywhere': The Abuse Case Against the Afghan FA

President, The Guardian (Dec. 27, 2018), https://www.theguardian.com/football/2018/dec/27/sexual-abuse-allegations-afghan-fa-president-keramuudin-karim.

135 See Mark A. Drumbl, Rights, Culture, and Crime: The Role of Rule of Law for the Women of Afghanistan, 42 Colum. J. Transnat'L L. 349 (2004).

136 FIFA Bans Afghan Football Official Over Sexual Abuse Scandal, AljazeEra (Oct. 11, 2019), https://www.aljazeera.com/news/2019/10/fifa-bans-afghan-football-official-sexual-abuse-scandal-191011135619821.html.

137 FIFA Code of Ethics, FIFA 20 (Aug. 12, 2018), https://resources.fifa.com/image/upload/fifacode-of-ethics-2018-version-takes-effect-12-08-18.pdf?cloudid=uemlkcy8wwdtll16sy3j.

138 Suzanne Wrack, Afghanistan's football president banned for life for sexual abuse, THE OBSERver (June 8, 2019), https://www.theguardian.com/football/2019/jun/08/keramuudin-karimbanned-for-life.
} 
and feel vindicated for the sexual harassment and abuse crimes he committed against them. But, this system failed before it worked. The case with the French Federation of Ice Sports was similar in that decades went by before authorities conducted thorough investigations into the perpetrator and held the NGB vicariously liable for failing to provide a safe environment for its athletes. The case in Afghanistan is perhaps an example for how the IOC, through its IFs, has the capability of instituting change, even in countries that lack effective criminal justice systems. Holding organizations vicariously liable for failing to prevent a hostile environment and act on sexual harassment and abuse allegations against individuals under its authority may also raise the level of urgency among IFs, NOCs, and NGBs to take a more active role in protecting athletes.

\section{The Structure of the Olympic Movement and its Governing Charter and Code of Ethics}

Given the persistence of sexual harassment and abuse in the Olympic Movement, it is apparent that the IOC's current policies and protections against this behavior are inadequate. The IOC, which leads the Olympic Movement, is by far the most important force in sports globally. However, the effort to eliminate sexual harassment and abuse in the Olympic Movement is an uphill battle. Not only is there extreme bureaucracy in the Olympic Movement's structure, but also the Olympic Movement's vague policies and lack of procedures to investigate and penalize sexual perpetrators expose the Olympic Movement's inadequacy in handling sexual harassment and abuse.

The bureaucratic behavior at the top of the Olympic structure isolates the IOC from the real problems that athletes face, including but not limited to sexual harassment and abuse. ${ }^{139}$ There have been several other examples where the IOC seemed out of step with the issues and concerns of athletes and the rest of the world. ${ }^{140}$ For example, at the time of the Sochi Olympics in 2014, the IOC failed to comment on the recent laws passed by Russian President Vladimir Putin that prohibited displays of homosexuality in Russia. ${ }^{141}$ Another disconnect occurred

\footnotetext{
139 Katherine Hampel, Whose Fault Is It?, 29 Marquette Sports L. Rev. 547, 554 (Spring 2019).

140 See Matthew Futterman, Why Olympic Leaders Clung to the Plan to Have the Summer Games in Tokyo, N.Y. Times (March 24, 2020), https://www.nytimes.com/2020/03/24/sports/olympics/ tokyo-olympics-postponed-coronavirus.html. 141 Id.
} 
in 2020, when the IOC resisted postponing the 2020 Summer Olympic Games in Tokyo for weeks even after doctors, sports officials, NGBs, and athletes concluded that conducting the Olympic Games during the COVID-19 pandemic would put the athletes' health at risk. ${ }^{142}$ The structure of the Olympic Movement also contributes to the IOC's failure to provide adequate protection of athletes from sexual harassment and abuse.

\section{A. The Structure of the Olympic Movement}

In 1892, Baron Pierre de Courbetin marked the birth of what is considered the modern Olympics by establishing the IOC. ${ }^{143}$ The IOC oversees the entire Olympic Movement, including the operation of the Olympic Games, the regulation of each Olympic sport, and the regulation of the Olympic organizing committees within each country and territory that participates in the Summer and Winter Olympic Games. ${ }^{144}$ The IOC recognizes IFs to serve as the worldwide governing bodies for each sport or group of sports played at the Olympic Games. ${ }^{145}$ As of 2020, the IOC recognized 39 IFs in total. ${ }^{146}$ Additionally, the IOC recognizes NOCs that are responsible for all Olympic activity in a particular country or territory. ${ }^{147} \mathrm{As}$ of 2018, the IOC recognized 206 NOCs. ${ }^{148}$ Each NOC also has the authority to recognize an NGB for each Olympic sport within its country or territory, which serves as that country or territory's representative in the IF for that particular sport. ${ }^{149}$ The NGB therefore has parallel reporting lines: one line to the NOC of its specific country or territory, and the other to the worldwide IF of that sport. ${ }^{150}$ This system results in a hierarchical structure with the IOC at the top, then the IFs and NOCs at the next level supervising the NGBs, and the athlete at the bottom.

\footnotetext{
142 Id.

143 Mitten, supra note 12 at 268.

144 Who We Are, supra note 7.

145 Mitten, supra note 12 at 270.

146 International Sports Federations, supra note 14.

147 MitTen, supra note 12.

148 National Olympic Committees, supra note 11.

149 See Mitten, supra note 12 at 271.

150 Id.
} 


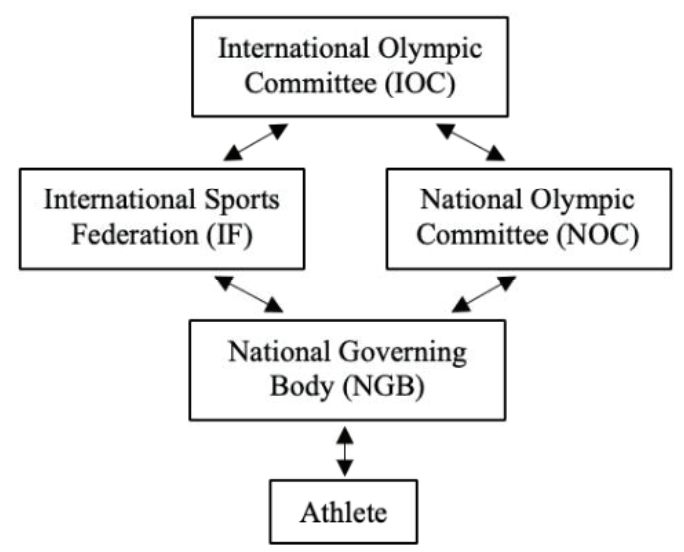

Figure 1. The Olympic Movement's governing structure.

Sexual harassment and abuse occur more commonly in organizations with hierarchical structures. ${ }^{151}$ The hierarchical structure of the Olympic Movement is an important reason why the IOC has failed to effectively regulate and enforce sexual harassment and abuse violations. The hierarchical structure allows a higher tier deniability, which is a way of avoiding accountability and responsibility for malfeasance in a lower tier. In the Nassar case, the USOC faced allegations that it failed to act on reports of sexual abuse by Nassar. ${ }^{152}$ However, the USOC tried to insulate itself from liability by arguing that it is only responsible for the care of athletes from the time the athletes are named to the Olympic team until the end of the Winter or Summer Olympic Games. ${ }^{153}$ As a result, the USOC disclaimed responsibility for failing to act on reports of sexual abuse by Nassar and instead pushed the responsibility to protect athletes from sexual abuse down to the NGB level. ${ }^{154}$ The lower tiers, on the other hand, will claim that their own sphere of responsibility is more narrow and will blame the higher supervisory tier. As a result, if each tier of the Olympic Movement believes that it is another tier's responsibility, then no organization will be responsible for protecting athletes from sexual harassment and abuse.

151 Anita M. Moorman \& Lisa P Masteralexis, An Examination of the Legal Framework Between Title VII and Title IX Sexual Harassment Claims in Athletics and Sports Settings: Emerging Challenges for Athletics Personnel and Sport Managers, J. of Legal Aspects of Sports 101, 107 (2011).

152 Jere Longman, Will Larry Nassar Take Down the U.S. Olympic Committee?, N.Y. Times (Jan. 25, 2018), https://www.nytimes.com/2018/01/25/sports/olympics/larry-nassar-usoc.html.

153 Id.

154 Id. 


\section{B. The Olympic Charter and the Olympic Agenda}

Historically, the IOC has been slow to address the issues of sexual harassment and abuse against athletes. The slow evolution of the IOC's Olympic Charter (Charter) is evidence of this. The Charter is a codification of the rules and bylaws that govern the IOC. The Charter has three main purposes: it 1) outlines the fundamental principles and values of Olympism; 2) serves as statutes for the IOC; and 3) defines the rights and obligations of the IOC, the IFs, and the NOCs. ${ }^{155}$ The Charter includes a mission statement proclaiming the IOC's role is to develop sport around the world, promote diversity in sport, and protect the spirit of fair play. ${ }^{156}$ The list of provisions in the Charter has expanded each year since the IOC's first Olympic Charter in 1908, but it was not until the 2019 version that the Charter included a provision that addressed the prevention of sexual harassment and abuse of athletes. ${ }^{157}$ The Charter's 18th provision states that the IOC's role is "to promote safe sport and the protection of athletes from all forms of harassment and abuse." 158

The IOC has continued to be slow to address the issue of sexual harassment and abuse in other Olympic directives. For example, sexual harassment and abuse was not addressed in the Olympic Agenda's 2020 list of 40 recommendations outlining the roadmap for the future success of the Olympic Movement. ${ }^{159}$ If the future goals of the IOC, as reflected in the Olympic Agenda, fail to stress the importance of protecting athletes from sexual harassment and abuse, then it sends a signal to perpetrators that the IOC is not taking an aggressive approach to combating sexual harassment and abuse in the Olympic Movement. The IOC still has a lot of progress to make in bolstering its commitment to the prevention of sexual harassment and abuse in the Olympic Movement.

\section{Olympic Code of Ethics}

The IOC Ethics Commission established a framework of ethical principles known as the Olympic Code of Ethics (Code). ${ }^{160}$ Article 1.4 of the Code states that Olympism rejects "all forms of harassment and abuse, be it physical, professional,

\footnotetext{
155 Olympic Charter, supra note 2, at 9.

156 Id. at art. 2, \1-18.

157 Id. at art. 2, ๆ 18.

158 Id.

159 See Olympic Agenda 2020: 20+20 Recommendations, InT'L Olympic Comm. (Dec. 2014), https://stillmed.olympic.org/Documents/Olympic_Agenda_2020/Olympic_Agenda_2020-20-20 Recommendations-ENG.pdf.

160 IOC Code of Ethics, InT’L Olympic Comm. 4 (2018), https://stillmed.olympic.org/media/Document\%20Library/OlympicOrg/Documents/Code-of-Ethics/2018/Code-of-Ethics-2018.pdf.
} 
or sexual, and any physical or mental injuries." 161 The Code also provides basic guidance as to how the IOC handles violations of sexual harassment and abuse. The sanctions for breaches of the Code include the IOC Ethics Commission issuing a warning, and "in the event of a serious breach ... the case shall be referred to the IOC Executive Board for possible sanctions." ${ }^{162}$ However, there is no guidance in the Code as to what type of sexual harassment and abuse conduct constitutes a "breach" compared to a "serious breach," which is a weakness of the Code. A second weakness is that besides issuing a warning, there is no notice of what possible further sanctions the IOC Executive Board would issue for a sexual harassment and abuse violation. ${ }^{163}$ The IOC needs to make its sexual harassment and abuse policies and sanctions more specific and more robust if it wants to make any progress in protecting athletes.

\section{Guidance from the IOC's Governance of Doping Violations Through WADA}

Unlike the vague measures the IOC has taken to date on sexual harassment and abuse, the IOC has codified extensive sanctions for doping violations. The IOC established the World Anti-Doping Agency (WADA) in 1999 with the goal of creating a world where athletes can compete on an equal playing field through a doping-free environment. ${ }^{164}$ In order to achieve this goal, WADA developed the WADA Code to document the anti-doping policies that all IFs, NOCs, NGBs, and athletes within those organizations must follow. ${ }^{165}$ Article 10 of WADA's Code lists the sanctions on individuals for violating doping policies, which include the disqualification of results from the event where the doping violation occurred, and temporary or permanent ineligibility from sport. ${ }^{166}$ Article 11 specifies the sanctions on teams for violating doping policies, including loss of points, disqualification from an event, and a ban from competing in the Olympic Games. ${ }^{167}$ And, Article 12 lists the sanctions on other sporting bodies for violating doping policies, which include the possibility of excluding all or some members of an IF, NOC, or NGB from future events. ${ }^{168}$

\footnotetext{
$161 \quad$ Id. at art. 1.4.

162 Id. at art. 26.

163 Id.

164 Who We Are, World Anti-Doping Agency, https://www.wada-ama.org/en/who-we-are (last visited April 4, 2020).

165 Id.

166 The World Anti-Doping Code 2021, World Anti-Doping Agency 34-46 (Nov. 29, 2019), https://www.wada-ama.org/sites/default/files/resources/files/2021 code.pdf.

$167 I d$. at 46.

168 Id. at 47.
} 
The WADA enforcement of doping violations has held athletes and Olympic organizations accountable. WADA applied Article 12 of the WADA Code after discovering the Russian government sponsored doping of Russian athletes during the 2014 Winter Olympic Games in Sochi. ${ }^{169}$ The investigation found that the Russian government authorized agents to swap positive urine samples for clean ones to shield Russian athletes from testing positive on drug tests. ${ }^{170}$ In accordance with Article 12, WADA banned Russia from competing in the next three Olympic Games and from bidding to host a major Olympic event. ${ }^{171}$ Although at least one sports columnist argued that the sanctions did not go far enough, ${ }^{172}$ the outcome of the Russian doping scandal is an example of how robust guidelines and sanctions for violations can be effective in holding countries and organizations liable for unethical conduct. The fact that the IOC has established an effective system through WADA and the WADA Code to discourage doping instills some confidence that the IOC could establish a system for investigating and sanctioning violators of sexual harassment and abuse as well.

\section{Administrative Systems in the Olympic Movement and Other Legislative Efforts Related to Sexual Harassment and Abuse Claims}

The IOC currently lacks a robust system to investigate and process sexual harassment and abuse allegations. Since its foundation, the IOC's Ethics Commission has been mostly preoccupied with bribery and self-dealing charges. ${ }^{173}$ Similarly, the Court of Arbitration of Sport has never heard a case related to sexual harassment and abuse. The fact that current systems of processing complaints have failed to cover sexual harassment and abuse violations shows that there is a gap in the Olympic Movement that needs to be filled. Efforts to fill this gap in the US through the Safe Sport Act and establishment of the U.S. Center for SafeSport have proven more effective. This section will review the IOC's current system for processing complaints, explore how the Court of

\footnotetext{
169 Tom Schad, Russia banned four years by WADA from international sports in latest punishment for doping violations, USA TODAY (Dec. 9, 2019), https:/www.usatoday.com/story/sports/olympics/2019/12/09/wada-bans-russia-four-years-doping-scandal-olympics/4376267002/.

170 Id.

171 Id.

172 Sally Jenkins, Banning Russia's flag and anthem is perfect for WADA, whose only concern is optics, The WASH. Post (Dec. 9, 2019), https://www.washingtonpost.com/sports/olympics/banningrussias-flag-and-anthem-is-perfect-for-wada-whose-only-concern-is-optics/2019/12/09/23a07c141aa5-11ea-87f7-f2e91143c60d story.html.

173 Ethics Commission, InT'L Olympic Comm., https://www.olympic.org/ethics-commission (last visited April 5, 2020); See “DECISIONS” filter.
} 
Arbitration of Sport could expand the types of disputes it settles to include sexual harassment and abuse, and examine the effectiveness of the Safe Sport Act and U.S. Center for SafeSport.

\section{A. Current IOC System for Processing Complaints}

The IOC established the Ethics Commission in 1999 in order to outline the ethical principles of the Olympic Movement, which resulted in the creation of the Code of Ethics. ${ }^{174}$ The Ethics Commission's responsibility is to analyze complaints and propose sanctions for violations of the Code of Ethics. ${ }^{175}$ If the Ethics Commission believes it needs more information on a complaint, it has the authority to conduct a confidential investigation. ${ }^{176}$ The Ethics Commission then makes conclusions and recommendations and delivers the report to the IOC Executive Board. ${ }^{177}$ The IOC Executive Board then determines the sanctions in accordance with the Olympic Charter. ${ }^{178}$

Since the Ethics Commission's formation in 1999, it has not made many rulings. ${ }^{179}$ The Ethics Commission has published only 42 rulings in the 21-year period since its inception. ${ }^{180}$ The emphasis has been on individual financial misconduct, with 30 out of the 42 rulings dealing with individuals at the IOC involved in bribery and self-dealing charges. ${ }^{181}$ Only nine of the cases have dealt with rulings against IFs and NOCs and none of the rulings related to sexual harassment and abuse. ${ }^{182}$ Clearly, the Olympic Charter and Code of Ethics are not yet providing the impetus necessary to combat the sexual harassment and abuse problem in the Olympic Movement. It is apparent that the IOC needs to amend the Charter and Code to clarify and establish robust sanctions for sexual harassment and abuse violations.

\section{B. Court of Arbitration for Sport}

The IOC created the Court of Arbitration for Sport (CAS) in 1984 to settle international sports-related disputes and to pronounce binding decisions on

\footnotetext{
174 Ethics Commission, InT'L Olympic Comm., https://www.olympic.org/ethics-commission (last visited March 24, 2020).

175 Id.

176 Id.

177 Id.

178 Id.

179 Ethics Commission, supra note 173.

180 See id.

181 See id.

182 See id.
} 
sports organizations and athletes. ${ }^{183}$ The creation of CAS addressed the need for uniformity in the governance of the Olympic Movement and for fairness and justice in athletic competitions. ${ }^{184}$ The IOC and all IFs, NOCs, and NGBs have agreed to CAS's jurisdiction. ${ }^{185}$ In addition, by-law 6 to Rule 44 of the Olympic Charter states all athletes and participants in the Olympic Games are subject to CAS jurisdiction and must comply with CAS's process. ${ }^{186}$ Therefore, all athletes, coaches, and staff that participate in an event or training program connected to the Olympic Games also agree to CAS's jurisdiction. ${ }^{187}$ CAS is not an investigative body; therefore, CAS does not engage in fact-finding related to the dispute. ${ }^{188}$ Instead, CAS mediates or arbitrates the dispute according to CAS's Code of Sports-related Arbitration. ${ }^{189}$ The CAS hears around 300 cases a year. ${ }^{190}$ Once CAS issues a decision, a party to the dispute may appeal CAS's decision to the Swiss Federal Tribunal only if there is a jurisdictional issue or violation of fundamental trial rights. ${ }^{191}$ Therefore, CAS's decisions are, in most cases, final and binding authority. ${ }^{192}$

CAS is a quasi-judicial body that uses arbitration or mediation to settle disputes in sport. ${ }^{193}$ Any athlete, club, sports federation, organizer of sports events, sponsor, or television company involved in a sports-related dispute may send a request for arbitration to CAS. ${ }^{194}$ The types of sports-related disputes that the CAS hears are either commercial or disciplinary in nature. ${ }^{195}$ Commercial disputes typically arise from disagreements related to sponsorship contracts, employment contracts, or event contracts. ${ }^{196}$ In contrast, disciplinary disputes include cases involving transgressive behavior related to athletes' doping violations, violence between athletes on the field of play, or unsportsmanlike conduct by a referee. ${ }^{197}$

\footnotetext{
183 History of the CAS, CT. OF ArB. For SpORT, https://www.tas-cas.org/en/general-information/ history-of-the-cas.html (last visited March 23, 2020).

184 MitTen, supra note 12 at 298.

185 History of the CAS, supra note 183.

186 Olympic Charter, supra note 2 at 80.

187 See id.

188 Id.

189 History of the CAS, supra note 183.

190 Frequently Asked Questions, Cт. оF Arв. For Sport, https://www.tas-cas.org/en/general-information/frequently-asked-questions.html (last visited April 5, 2020).

191 Id.

192 See id.

193 Id.

194 Id.

195 Id.

196 Id.

197 Id.
} 
CAS has never heard a case related to sexual harassment and abuse violations, ${ }^{198}$ even though these cases would seem to fall under the disciplinary category. This is probably because the IOC does not have clear policies and procedures to appeal a sexual harassment and abuse case to the CAS.

\section{United States Policy-Making on Sexual Harassment and Abuse in Sports}

A recent model for processing sexual harassment and abuse allegations of athletes is legislation titled "Protecting Victims from Sexual Abuse and Safe Sport Authorization Act of 2017," which the U.S. Congress passed in 2018. ${ }^{199}$ Following the Nassar scandal, several U.S. Congressmen realized that the US needed laws to protect victims from sexual harassment and abuse in sports. The Safe Sport Act (Act) requires any adult who is a member of an NGB in the US, or interacts with a minor at an NGB's facility or at any event sanctioned by an NGB, to report any incident of sexual harassment and abuse to law enforcement within 24 hours. ${ }^{200}$ This Act places a legal duty on any adults aware of potential sexual harassment and abuse to promptly report the violation. A person who fails to notify law enforcement under this Act could face a fine or imprisonment of up to one year. ${ }^{201}$ In addition, the Act creates a remedy for victims of sexual harassment and abuse to receive compensation in the amount of $\$ 150,000 .{ }^{202}$ Though a dollar amount cannot be placed on the pain and suffering sexual harassment and abuse victims endure, providing some monetary relief acknowledges that victims should receive some reparations.

The Act established the U.S. Center for SafeSport (Center) to implement the goals of the Act. ${ }^{203}$ The Center has jurisdiction over all Olympic activity, the USOC, and the NGBs in the US. ${ }^{204}$ The Center's purpose is to protect minor athletes from sexual harassment and abuse in sports by developing educational programs, creating mandatory reporting policies, and resolving sexual abuse allegations. ${ }^{205}$ After a thorough investigation, if the Center finds a sexual harassment and abuse

\footnotetext{
198 See id.

199 S.534 Protecting Young Victims from Sexual Abuse and Safe Sport Authorization Act, U.S. Libr. of Cong. (Feb. 14, 2018), https://www.congress.gov/bill/115th-congress/senate-bill/534; Protecting Young Victims from Sexual Abuse and Safe Sport Authorization Act of 2017, 36 U.S.C.A. $\S 220541$ (2018) [hereinafter Safe Sport Act]. 
violation, it may penalize the perpetrator by issuing a warning, probation, suspension, or even imposing permanent ineligibility. ${ }^{206}$ If the perpetrator disagrees with the Center's decision, the perpetrator can ask the American Arbitration Association to review the decision. ${ }^{207}$ Since launching in March 2017, the Center has been extraordinarily productive. From 2017-2019, the Center received nearly 5,000 reports of sexual harassment and abuse and sanctioned 627 individuals for emotional, physical, or sexual harassment and abuse of minor athletes. ${ }^{208}$ The Center has also permanently banned 279 individuals from participating in any capacity relating to a program, event, or activity with a connection to the USOC. ${ }^{209}$ The Center still had more than 1,200 open cases as of September 2019. ${ }^{210}$ In addition, the Center maintains a publicly available database of all the sanctioned and permanently banned individuals and lists 1,218 names as of December 2019. ${ }^{211}$ If the public takes advantage of this database, it can minimize the risk that a perpetrator will move on to another position in sports.

The Center also created a SafeSport Code to govern sexual harassment and abuse policies of the USOC, the NGBs, and the local affiliated organizations in the US. ${ }^{212}$ Some NGBs in the US have created their own SafeSport policies that meet the requirements outlined in the Center's SafeSport Code. ${ }^{213}$ For example, USA Gymnastics' Safe Sport Policy applies to all USA Gymnastics members and participants, ${ }^{214}$ which currently includes more than 200,000 athletes and professionals. ${ }^{215}$ The policy states that it is mandatory for all adults under USA

\footnotetext{
206 SafeSport Code for the Olympic and Paralympic Movements, U.S. CTR. FOR SAFESPort 29 (April 15, 2019), https://uscenterforsafesport.org/wp-content/uploads/2019/05/2019-SafeSport-Code-04.15.19-Hyperlinked.pdf.

207 Id. at 30.

208 U.S. Center for SafeSport 2019 Annual Report, supra note 72 at 4, 6.

209 U.S. Center for Safe Sport Data, U.S. CTR. FOR SAFESport (Aug. 31, 2020), https://uscenterforsafesport.org/wp-content/uploads/2020/09/Center-Overview-8.31.2020.pdf

210 Karma Allen, Reports of sexual abuse, misconduct in Olympic sports up 55\% from last year, ABC News (Sept. 17, 2019), https://abcnews.go.com/US/reports-sexual-abuse-misconduct-olympic-sports-55-year/story?id=65680795.

211 Centralized Disciplinary Database, U.S. CTR. FOR SAFESPORT, https://uscenterforsafesport. org/response-and-resolution/disciplinary-database/ (last visited March 23, 2020); U.S. Center for SafeSport 2019 Annual Report, supra note 72 at 4.

212 SafeSport Code for the U.S. Olympic and Paralympic Movements, U.S. CTR. FOR SAFESPORT 1 (April 15, 2019), https://uscenterforsafesport.org/wp-content/uploads/2019/05/2019-SafeSport-Code-04.15.19-Hyperlinked.pdf.

213 See USA Gymnastics Safe Sport Policy, USA Gymnastics (Oct. 2019), https://usagym.org/ PDFs/safesport/policy.pdf; US Equestrian Federation Safe Sport Policy, US Equestrian Fed'n (Jan. 1, 2020), https://www.usef.org/forms-pubs/YXj0R68pxq0/safe-sport-policy.

214 USA Gymnastics Safe Sport Policy, USA Gymnastics 2 (Oct. 2019), https://usagym.org/PDFs/ safesport/policy.pdf.

215 About USA Gymnastics, supra note 92.
} 
Gymnastics' jurisdiction to report sexual misconduct to the Center. ${ }^{216}$ Sexual misconduct includes: 1) sexual contact with a minor; 2) sexual or gender-related harassment; 3) non-consensual sexual contact; 4) non-consensual sexual intercourse; 5) sexual exploitation; 6) bullying or hazing, or other inappropriate conduct of a sexual nature; or 7) other inappropriate conduct. ${ }^{217}$ The USA Gymnastics' Code defines "other inappropriate conduct" to include engaging in an intimate relationship, or inappropriate physical contact with an athlete when a power imbalance exists. ${ }^{218}$ A power imbalance may exist where, "based on the totality of the circumstances, one person has supervisory, evaluative, or other authority over another." ${ }^{219}$ Further, a power imbalance is presumed to exist in a coach-athlete relationship regardless of the age of the parties. ${ }^{220}$ Since the Center issued its first disciplinary decision in July 2017, the Center has filed disciplinary actions against 91 people involved with USA Gymnastics for violations of the Safe Sport Code. ${ }^{221}$ Though the Center has only been in operation for three years, the fact that the Center projects it needs to double its staff in 2020 and triple its staff by 2023 illustrates the strong demand for investigating claims of sexual harassment and abuse against athletes. ${ }^{222}$

The Act also required the Center to produce training materials to educate the NGBs and other organizations on sexual harassment and abuse. ${ }^{223}$ All athletes, coaches, officials, and other adult members of a NGB are required to take a SafeSport training course. ${ }^{24}$ The Center has also created guides for athletes and parents of athletes to educate them on best practices to prevent sexual harassment and abuse in sport. ${ }^{225}$ Since launching in March 2017, more than 1.6 million individuals have completed the Safe Sport training course. ${ }^{226}$ From the increase in staff, the number of sanctions issued, and the number of training courses administered, it is evident that the Center has been remarkably effective.

\footnotetext{
216 USA Gymnastics Safe Sport Policy, supra note 214, at 2.

217 Id. at 11.

218 Id. at 12.

219 SafeSport Code for the U.S. Olympic and Paralympic Movements, U.S. CTR. FOr SAFESPORT 6 (April 15, 2019), https://uscenterforsafesport.org/wp-content/uploads/2019/05/2019-SafeSport-Code-04.15.19-Hyperlinked.pdf [hereinafter SafeSport Code].

220 USA Gymnastics Safe Sport Policy, supra note 214, at 4.

221 Centralized Disciplinary Database, supra note 211, filter by sport affiliation "USA Gymnastics" and adjudicating body "U.S. Center for SafeSport".

222 Allen, supra note 210.

223 Safe Sport Act, supra note 199, at Sec. (a)(3).

224 Training Resources for NGBs, U.S. CTR. FOR SAFESPORT, https:/uscenterforsafesport.org/ ngb-services/training/ (last visited April 5, 2020).

225 See id.

226 U.S. Center for Safe Sport Data, supra note 209.
} 
While the Act and Center has had an enormous impact on sports in the US, the Olympic Movement needs to provide protection from sexual harassment and abuse to all athletes around the world, especially in jurisdictions where criminal courts fail to provide needed protection. US courts are generally reluctant to use domestic laws to regulate the Olympics and international sports competitions because the IOC and international competitions fall outside the US jurisdiction. ${ }^{227}$ Additionally, athletes from more than 206 countries and territories are part of the Olympic Movement, ${ }^{228}$ and every two years the IOC hosts the Summer and Winter Olympic Games in a different country. Therefore, without a decision maker with overarching jurisdiction, cases involving Olympic athletes being sexual harassed and abused would have to be brought in different countries with different laws each time the Olympic Games are held. As a result, the Olympic Movement must provide a system that would fill jurisdictional gaps and allow for more uniformity and predictability across sexual harassment and abuse violations.

\section{Recommendations for the IOC}

This article provides five recommendations for increasing protection for Olympic athletes from sexual harassment and abuse. First, efforts in this area should begin with the IOC. The IOC's position at the top of the Olympic Movement's governing structure gives the IOC power over the IFs, NOCs, NGBs, athletes, coaches, trainers, and all other individuals associated with the Olympic Movement. A top-down approach starting with the IOC will show that the Olympic Movement is taking a step forward in prioritizing the safety of its athletes. Therefore, the IOC should take advantage of its position and be a leader in this area.

Second, the IOC should update its codes and policies related to sexual harassment and abuse. The IOC's current body of codes and policies are too vague. The Olympic Charter and Code of Ethics should be supplemented with provisions that clearly define the behavior that constitutes sexual harassment and abuse, the process to report and investigate allegations, and the sanctions for violating the policies. The IOC should consider the WADA model, and replicate the specificity and rigor of the WADA Code.

Third, the IOC should implement mandatory education and training programs for organizations within the Olympic Movement. Programs and materials to educate the IFs, NOCs, NGBs and all individuals that are part of the Olympic Movement on what behavior constitutes sexual harassment and abuse, and what measures could be implemented to curb and prevent sexual harassment and abuse would help increase awareness on this issue.

\footnotetext{
227 Mitten, supra note 12, at 289-90.

228 Amelia Warshaw, The 2016 Rio Olympics by the Numbers, DAILY BeAst (Aug. 7, 2016), https:// www.thedailybeast.com/the-2016-rio-olympics-by-the-numbers.
} 
Fourth, the IOC should hold organizations, not simply individuals, liable for sexual harassment and abuse violations. The IOC should make clear that organizations under the IOC, such as the IFs, NOCs, and NGBs will be held vicariously liable for sexual harassment and abuse violations of individuals under their purview. Having a system of accountability similar to what Title VII of the Civil Rights Act has established in the US will encourage organizations to take sexual harassment and abuse allegations more seriously and implement safeguards to limit this behavior altogether.

Fifth, the IOC should sponsor a Global Center for SafeSport modeled after the U.S. Center for SafeSport. Other countries may not have the resources the US has to create a Center for SafeSport, but all athletes under the Olympic Movement would benefit from having one. The IOC should implement a Global Center for SafeSport at the international level. The Global Center for SafeSport would be responsible for developing a Global SafeSport Code that prohibits all forms of abuse against athletes in the Olympic Movement. All individuals and organizations that have any connection with the Olympic Movement would be under the authority of this code. The Global Center for SafeSport would have the authority to investigate any sexual harassment and abuse allegation made in connection with the Olympic Movement. The Global SafeSport Code would also outline robust sanctions against individual perpetrators and provide for sanctions against an IF, NOC, or NGB when the organization is found vicariously liable. Those who disagree with the Global Center for SafeSport's decision would have the right to appeal the case to the CAS for review. The Global Center for SafeSport would be responsible for providing educational and training materials to all IFs, NOCs, NGBs, and for assuring these organizations are in compliance with the Global Center's SafeSport Code. Creating a Global Center for SafeSport would ensure that the IOC and the CAS have jurisdiction over all sexual harassment and abuse violations in the Olympic Movement, regardless of the nationality of the victim, the nationality of the sexual perpetrator, or the country where the violation occurred. As a result, establishing a Global Center for SafeSport would increase the likelihood that all athletes in the Olympic Movement would receive the same protection from sexual harassment and abuse.

\section{Conclusion}

Sexual harassment and abuse of athletes is an ongoing problem affecting athletes in the Olympic Movement. Globally, awareness of sexual harassment and abuse in sports has increased particularly with the \#MeToo movement and the prosecution and sanctions against some high-profile offenders including Nassar, Gailhaguet, and Karim. The IOC has proven slow in both developing robust policies preventing sexual harassment and abuse, and in holding sexual perpetrators and 
governing organizations accountable for their actions. Though the IOC does face legitimate challenges creating policies that cover a vast number of sports and countries with cultural differences, the IOC needs to attempt to overcome these challenges. The IOC should leverage its status as the governing authority of the Olympic Movement to implement a robust system that protects athletes from sexual harassment and abuse. This system would not only hold individual perpetrators accountable, but would also hold IFs, NOCs, and NGBs liable for the failure to create and maintain a safe environment for athletes, similar to the way Title VII of the Civil Rights Act of 1964 imposes vicarious liability on institutions in the US. The Safe Sports Act and the U.S. Center for SafeSport are also good models for the IOC to follow. The IOC should establish a Global Center for SafeSport with the same purpose and powers of the U.S. Center for SafeSport to give policies prohibiting sexual harassment and abuse an international reach. The Global Center for SafeSport would also have authority similar to WADA to sanction individuals, teams, and other sporting bodies that violate these policies. A Global Center for SafeSport would be a major step forward in the effort to protect athletes in the Olympic Movement from sexual harassment and abuse. 